\title{
A Study on the Fine Structure of the Marine Diatoms of Korean Coastal Waters - Genus Thalassiosira 3
}

\author{
Jin Hwan Lee* and Joon Sang Park \\ Department of Biology, Sangmyung University, Seoul 110-743, Korea
}

\begin{abstract}
A study on the fine structure of the marine diatom Thalassiosira has been carried out during the periods from January 2007 to March 2008 in Korean coastal waters. As the third series of the Thalassiosira species, a fine structure, description, distribution and taxonomic remarks of the six Thalassiosira species were observed by means of light microscope and scanning electron microscope. The critical features of Thalassiosira species were a shape of external tubes of marginal strutted processes and labiate process. Six species showed each different shape of external tubes, marginal strutted processes and labiate process. The shape of external tube was divided into five types: T shape of Thalassiosira curviseriata, small-rounded shape of T. lundiana, double-layer form and flame shape of $T$. nordenskioeldii, tulip shape of T. punctigera and tooth-shape of T. tenera. This external character may be able to key character for positive identification of the Thalassiosira species. Of these Thalassiosira lundiana, T. minuscula and T. tenera were new records for Korean coastal waters.
\end{abstract}

Key Words: external tube, fine structure, Korea, labiate process, strutted process, Thalassiosira

\section{INTRODUCTION}

The genus Thalassiosira was erected by Cleve (1873), and the description was emended by Hasle (1973). Various authors have mentioned that the number of species of the genus Thalassiosira may exceed 100 taxa (Round et al. 1990; Hasle and Syversten 1996). Regional investigations, some of them including descriptions of new species, have been published in a high number since the first transmission electron microscopy (TEM) examinations started to appear in the 1950s (Helmcke and Krieger 1953, 1954) and the first examinations taking with SEM in the 1960s (Hasle 1968). Attempts have been made to impose structure on this genus which seems to increase in number of species parallel to the number of localities investigated. This figure and the morphological complexity of the genus make positive species identification difficult. The most important characters for species identification are the feature of strutted and labiate processes on the valve face (Hasle 1968, 1973). Hasle and Syvertsen (1996) redefined the original subgroups as proposed by Hasle (1968). Makarova (1988) suggested a system that is based on the pattern of the areolae for divid-

*Corresponding author (jhlee@smu.ac.kr) ing the genus into smaller groups. However, a number of studies have shown that areolation is often influenced by environmental factors (Hasle 1978; Hallegraeff 1984; Syvertsen and Hasle 1984).

Lee and Cho (1985) listed up a total of 18 taxa of Thalassiosira species in Korean coastal waters. These species have been merely limited to the list of inventory. Lee and Yoo $(1986,1987)$ have studied a fine structure of the genus Thalassiosira from Korean coastal waters and reported 6 Thalassiosira species as new records for Korean coastal waters. Lee (1995) have listed up a total of 761 taxa including 653 species, 89 varieties, 10 forma and 3 others of phytoplankton diatoms in the Korean coastal waters. Of these, the genus Thalassiosira species have been recognized 25 species.

The present study was carried out as a series of the third of the fine structure, description, distribution and taxonomic remarks of the six Thalassiosira species by light microscope and scanning electron microscope observations in Korean coastal waters.

\section{MATERIALS AND METHODS}

Material figured were collected in the Korean coastal waters during the periods from July 2006 to March 2008. Table 1 shows the sampling locations. Fixed materials 
Table 1. Collection data of Thalassiosira species in Korean costal waters

\begin{tabular}{|c|c|c|c|c|}
\hline Species & Date & Locality & Latitude (N) & Longitude (E) \\
\hline \multirow[t]{3}{*}{ Thalassiosira curviserita } & Sep. 28, 2007 & Ulsan Bay & $35^{\circ} 28^{\prime} 46^{\prime \prime}$ & $129^{\circ} 23^{\prime} 45^{\prime \prime}$ \\
\hline & Feb. 24, 2008 & Incheon coast & $37^{\circ} 22^{\prime} 20^{\prime \prime}$ & $126^{\circ} 32^{\prime} 13^{\prime \prime}$ \\
\hline & Mar. 23, 2008 & Dangin coast & $36^{\circ} 26^{\prime} 35^{\prime \prime}$ & $126^{\circ} 33^{\prime} 41^{\prime \prime}$ \\
\hline \multirow[t]{2}{*}{ T. lundiana } & Sep. 28, 2007 & Ulsan Bay & $35^{\circ} 28^{\prime} 46^{\prime \prime}$ & $129^{\circ} 23^{\prime} 45^{\prime \prime}$ \\
\hline & Mar. 4, 2008 & & & \\
\hline \multirow[t]{2}{*}{ T. minuscula } & Jan. 18, 2007 & Taean coast & $36^{\circ} 24^{\prime} 09^{\prime \prime}$ & $126^{\circ} 24^{\prime} 06^{\prime \prime}$ \\
\hline & Jan. 13, 2007 & Tongyeong coast & $34^{\circ} 46^{\prime} 12^{\prime \prime}$ & $128^{\circ} 23^{\prime} 61^{\prime \prime}$ \\
\hline \multirow[t]{2}{*}{ T. nordenskioeldii } & Sep. 28, 2007 & Ulsan Bay & $35^{\circ} 28^{\prime} 46^{\prime \prime}$ & $129^{\circ} 23^{\prime} 45^{\prime \prime}$ \\
\hline & Mar. 23, 2008 & Dagin coast & $36^{\circ} 26^{\prime} 35^{\prime \prime}$ & $126^{\circ} 33^{\prime} 41^{\prime \prime}$ \\
\hline T. punctigera & Jan. 13, 2007 & Tongyeong coast & $34^{\circ} 46^{\prime} 12^{\prime \prime}$ & $128^{\circ} 23^{\prime} 61^{\prime \prime}$ \\
\hline \multirow[t]{2}{*}{ T. tenera } & Sep. 28, 2007 & Ulsan Bay & $35^{\circ} 28^{\prime} 46^{\prime \prime}$ & $129^{\circ} 23^{\prime} 45^{\prime \prime}$ \\
\hline & Mar. 23, 2008 & Seocheon coast & $36^{\circ} 10^{\prime} 26^{\prime \prime}$ & $126^{\circ} 31^{\prime} 30^{\prime \prime}$ \\
\hline
\end{tabular}

were collected with $20 \mu \mathrm{m}$ mesh nets in vertical towing and were in situ fixed with 5\% neutralized formalin. (Hasle and Fryxell 1970) and mounted in pleurax for Light Microscope and on aluminum stubs for Scanning Electron Microscope. Materials was coated with goldpalladium and examined with SEM (JSM-5600LV, Japan). Terminology is that suggested by the Working Party on Diatom Terminology (Anonymous 1975).

\section{RESULTS AND DISCUSSION}

The present study was adopted Simonsen's (1979) systematic system based on ideas of phylogeny as follows;

\author{
Class Bacillariophyceae Haeckel 1878 \\ Order Centrales Hustedt 1930 \\ Suborder Coscinodiscineae Simonsen 1979 \\ Family Thalassiosiraceae Lebour 1930, emend. \\ Hasle 1973 \\ Genus Thalassiosira Cleve 1873 \\ Thalassiosira curviseriata Takano 1981 \\ T. lundiana Fryxell 1975 \\ T. minuscula Krasske 1941 \\ T. nordenskioeldii Cleve 1873 \\ T. punctigera Hasle 1983 \\ T. tenera Proschkina-Lavrenko 1961
}

A total of six species of the genus Thalassiosira have been identified during the present study; Thalassiosira curviseriata, T. lundiana, T. minuscula, T. nordenskioeldii, T. punctigera and T. tenera. Of these Thalassiosira lundiana, $T$. minuscula and T. tenera were new records for Korean coastal waters.

\section{Description of the species}

Thalassiosira curviseriata Takano (Pl. I, Figs 1-6)

Takano 1981, p. 34, Figs 26-38; Hallegraeff 1984, p. 498, Fig. 8; Takano 1983, sheet 123, Figs A-H; Hoppenrath et al. 2007, p. 276, Figs 13-15.

Cells elliptical to octagonal in the girdle view. Cells 8$10 \mu \mathrm{m}$ in diameter. Valve areolae with radial rows. Number of areolae 20 to 25 in $10 \mu \mathrm{m}$. Valve face covered with siliceous granules. Marginal hyaline developed very well. One or two central strutted processes next to an annulus. One marginal ring of 4 to 7 conspicuous winged strutted processes showing two wings per process diverging into 2-3 branches. One slitted-labiate process present adjacent to a marginal strutted process and also external tube present. In the internal view, central strutted process composed with 3 satellite pores, whereas marginal strutted process with 4 satellite pores.

Distribution: Thalassiosira curviseriata was known to cosmopolitan species excluding polar regions (Hoppenrath et al. 2007). In Korea, T. curvieriata was previously reported one time in Jinhae bay (Han et al. 1994). The present study was recorded three times in September 28, 2007 in Ulsan Bay, February 24, 2008 in Incheon coastal water and March 23, 2008 in Dangjin coastal water.

\section{Taxonomic remarks}

Takano (1981) have distinguished Thalassiosira curviseriata from T. tealata Proshkina-Lavrenko by the shape of external tube of marginal strutted processes. The tube was " $\mathrm{T}$ " shape and as similar species $T$. tealata also have same shape of external tube. Takano (1980a, 1981) have mentioned that marginal strutted process of $T$. curviseriata have two wings diverging into 2-3 branches, whereas in $T$. tealata the long wings each have a single slender tip. 

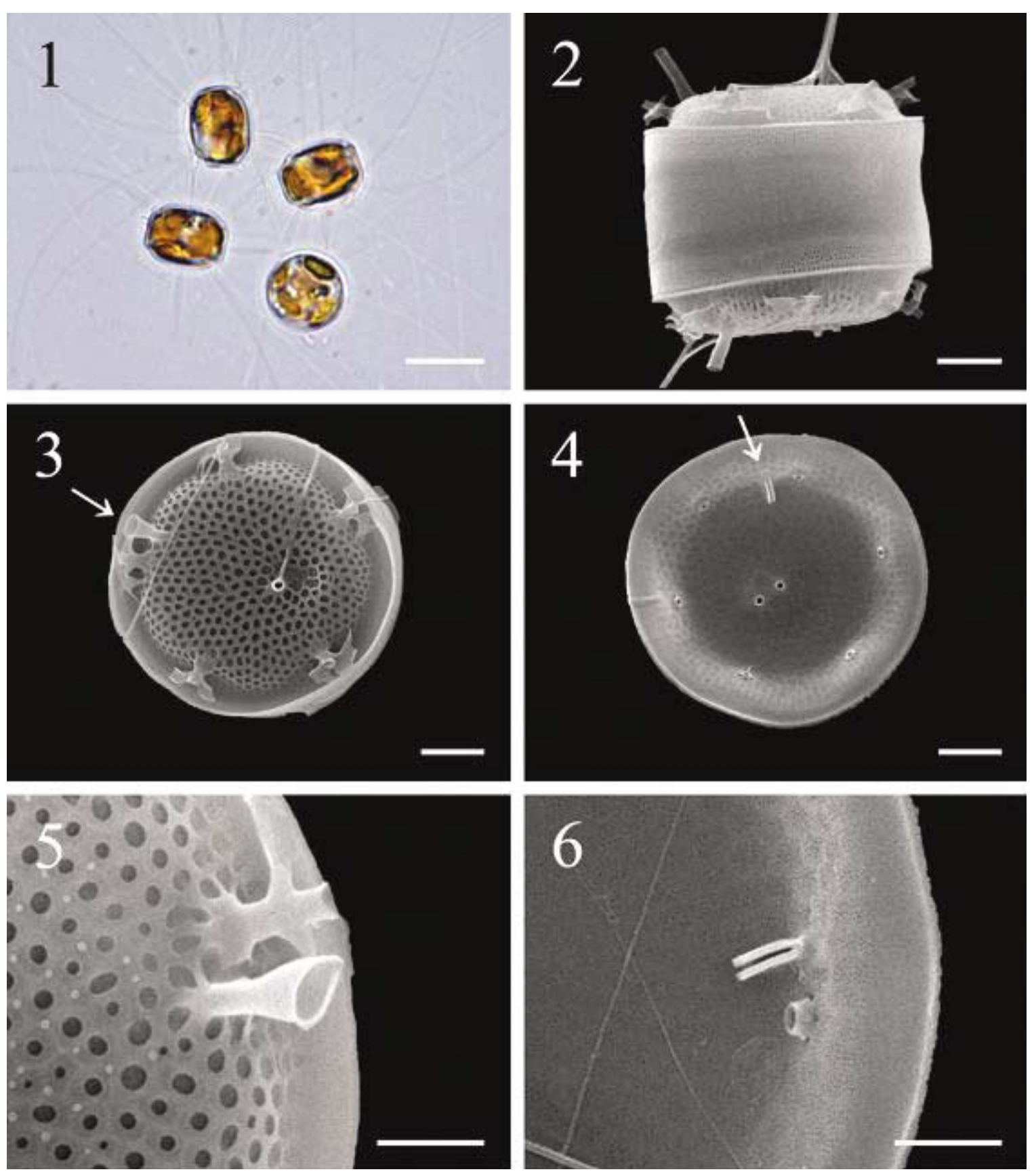

Plate I. Thalassiosira curviseriata, LM and SEM. Fig. 1. LM. Fig. 2. External girdle view. Fig. 3. External valve view. Arrow indicates the external tube of labiate process. Fig. 4. Internal valve view. Arrow indicates the labiate process. Fig. 5. External tube of the labiate process with a marginal strutted process. Fig. 6. Focusing on the labiate process and a marginal strutted process. Scale bar: $10 \mu \mathrm{m}$ (Fig. 1), $2 \mu \mathrm{m}$ (Figs 2-4), $1 \mu \mathrm{m}$ (Figs 5, 6).

Hoppenrath et al. (2007) mentioned that simply the morphological variability of two species requires reinvestigation with morphometric and genetic analyses of clonal culture.

\section{Thalassiosira lundiana Fryxell (P1. II, Figs 7-12)}

Fryxell 1975, p. 362-363, Pl. 3, 4, Figs 12-24; Takano 1979a, sheet 14, Figs A-F; Mahood et al. 1986, p. 137, Figs
38-41; Hoppenrath et al. 2007, p. 279, Figs 31-32.

Cells slightly convex in the girdle view. Cells $10-36 \mu \mathrm{m}$ in diameter. Valve with fine areolae arranged in sectors, fasciculated and marginal striae. Number of areolae 17 to 36 in $10 \mu \mathrm{m}$. One central strutted processes next to an annulus, and composed with 3 or 4 satellite pores. One marginal ring of strutted processes showing zigzag form arrangements. Several or many strutted processes scat- 

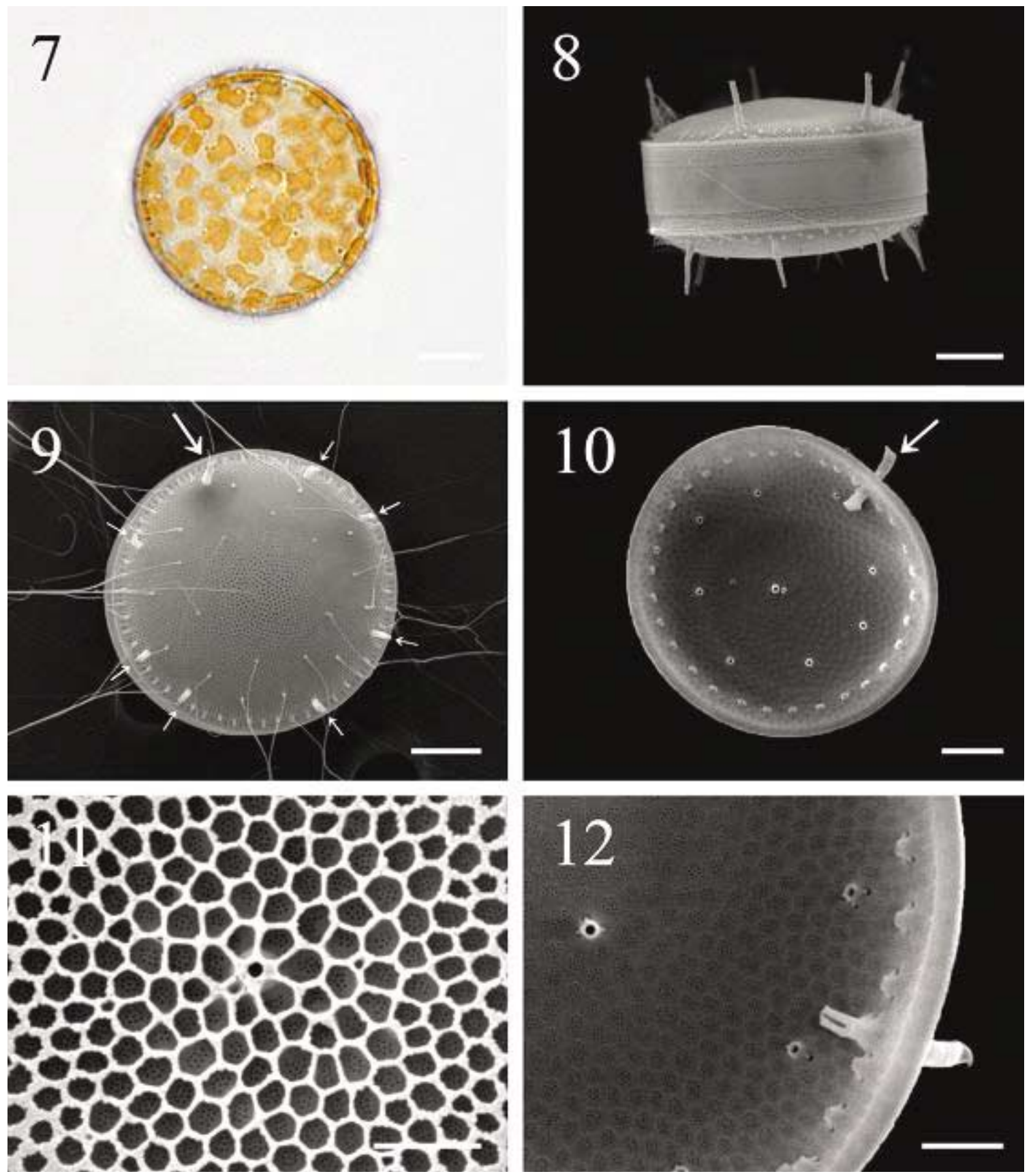

Plate II. Thalassiosira lundiana, LM and SEM. Fig. 7. LM. Fig. 8. External girdle view. Fig. 9. External valve view. Large arrow indicates the external tube of labiate process and small arrows occluded processes. Fig. 10. Internal valve view. Arrow indicates the labiate process. Fig. 11. Central strutted process and areolation. Fig. 12. Marginal labiate process and one marginal ring of strutted processes. Scale bar: $10 \mu \mathrm{m}$ (Fig. 7), $5 \mu \mathrm{m}$ (Figs 8, 9), $2 \mu \mathrm{m}$ (Fig. 10), $1 \mu \mathrm{m}$ (Figs 11, 12).

tered on the valve face. One submarginal ring of occluded processes present. One external tube of labiate process positioned between marginal strutted processes. In the internal view, marginal and valve strutted process composed with 2 or 3 satellite pores.

Distribution: Fryxell (1975) reported that Thalassiosira lundiana found in the Atlantic Ocean, off West Africa and off South Africa, as well as in the Pacific Ocean at Rocky
Point, Mexico, in the Gulf of California, and the northern Pacific. She has been isolated this species near the mouth of the Missisippi River ranging from 21 to 38 , it can be assumed euryhaline species. Thalassiosira lundiana was unknown to the Korean coastal waters till up to present. Our samples were collected in July 28, 2007 and March 4, 2008 in Ulsan Bay. T. lundiana was reported for the first time in Korean coastal waters. 


\section{Taxonomic remarks}

Fryxell (1975) mentioned that occluded processes of this species are a striking feature. Occluded processes feature is closely related to $T$. punctigera (Castracane) Hasle and T. licea Fryxell. However, this process may or not be only present in the three species. And she also mentioned that $T$. lundiana has strutted processes scattered on the valve face, but clear patterns are not evident. The present study was observed that small-sized T. lundiana has submarginal ring of strutted processes instead of scattered strutted processes. This species have similar with the external tube of marginal strutted processes of T. rotula.

\section{Thalassiosira minuscula Krasske (P1. III, Figs 13-18)}

Krasske 1941, p. 262, Pl. 5, Figs 4-6; Simonsen 1974, p. 10; Hasle 1976a, p. 104, Figs 6-10; Rivera 1981, p. 95 Figs 246-262; Hallegraeff 1984, p. 497, Figs 4a-b; HernándezBecerril and Tapis-Peña 1995, p. 550, Figs 49-60; AkéCastillo et al. 1999, p. 494, Fig. 20; Hoppenrath et al. 2007, p. 279, Figs 38-40.

Synonym: Thalassiosira monoporocyclus Hasle 1972, p. 129, Figs 49-60.

Chloroplast discoidal, fully, peripheral in LM. Cell shape convex in the girdle view. Cells $10-36 \mu \mathrm{m}$ in diameter. Valve face with fine areolae arranged in rows from parallel to radial. Areolae 17 to 36 in $10 \mu \mathrm{m}$ in the whole valve. One central strutted process and one marginal ring of strutted processes. One labiate process located between marginal strutted process. External tube of labiate process invisible, but large and slitted large-sized labiate process in the internal view. In the internal view, all strutted processes composed with 4 satellite pores.

Distribution: Thalassiosira minuscula was known to warm water species (Hasle 1972, 1976a). T. minuscula was found in January 18, 2007 in Taean coast and January 13, 2007 in Tongyeong coast and recorded new to Korea.

\section{Taxonomic remarks}

Thalassiosira minuscula was not showed the external tube. Hasle and Syvertsen (1996) mentioned that due to the lack of external process tubes and the location of the labiate process at some distance from the valve margin. All Thalassiosira species were divided into two group A and B by Hasle and Syvertsen (1996). T. minuscula could just as well be placed into group B as in group A. Unlike species of group B, T. minuscula has short internal tubes, a feature shared with $T$. subtilis, $T$. diporocyclus, and $T$. fragilis, all appearing in mucilage colonies.
Thalassiosira nordenskioeldii Cleve (P1. IV, Figs 19-26)

Cleve 1873, p. 7, Pl. Fig. 1; Hustedt 1930, p. 321, Fig. 157; Cupp 1943, p. 46, Fig. 8; Hendey 1964, p. 85, Pl. 1, Fig. 8; Hasle 1976b, p. 323, Figs 4-7; Hasle 1978, p. 79, Figs 1, 5-20; Takano 1979b, sheet 9, Figs A-F; Hoppenrath et al. 2007, p. 281, Figs 41-43.

Cells octagonal in the girdle view. Cells $11-41 \mu \mathrm{m}$ in diameter. Diameters three times wider than pervalvar axis. Valve with hexagonal areolae in sectors. Number of areolae 4 to 5 in $10 \mu \mathrm{m}$. One central strutted process next to an annulus. One marginal ring of prominent strutted processes with long external tubes and about 3 in $10 \mu \mathrm{m}$. Marginal strutted processes with double layers. Out layer flame form at the top. One large tube-like labiate process located in the marginal ring of strutted processes. In internal view, all strutted processes composed with 4 satellite pores.

Distribution: Thalassiosira nordenskioeldii was found to about $50^{\circ} \mathrm{N}$ in the eastern and to about $40^{\circ} \mathrm{N}$ in the western Atlantic coastal waters and to about $35^{\circ} \mathrm{N}$ in the Pacific Ocean (Hasle 1976b). T. nordenskioeldii was reportded in cold to temperate waters (Hasle and Syversten 1996). In Korean coastal waters, T. nordenskioeldii was recorded 18 times till the year of 1990's (Lee 1995). The present study was recorded in September 28, 2007 and March 23, 2008 in Taean and Dangjin coastal waters, respectively.

\section{Taxonomic remarks}

Thalassiosira nordenskioeldii is type species of the genus Thalassiosira. Hasle (1978) mentioned that in spite of useful information already available, they feel that the morphology of $T$. nordenskioeldii as the type species of the genus deserves a detailed discussion. And she characterized $T$. nordenskioeldii by valve face structure, areolae pattern, position of marginal strutted processes and labiate process, but she didn't mentioned about shape of the marginal strutted processes. Hasle and Fryxell (1977) mentioned that external tubes of marginal strutted processes were described many terms as "skirt", "collar". Our T. nordenskioeldii specimens were also observed double layers tube shape and we described the shape as "flame".

\section{Thalassiosira punctigera Hasle (P1. V, Figs 27-34)}

Castracane 1886, p. 167, Pl. 3, Fig. 1; Makarova 1970, p. 13; Fryxell 1978, p. 133, Figs 9-20; Takano 1980b, sheet 32, Figs A-H; Hasle 1983, Figs 1-45; Makarova 1988, p. 67, P1. 38, Figs 1-10. 

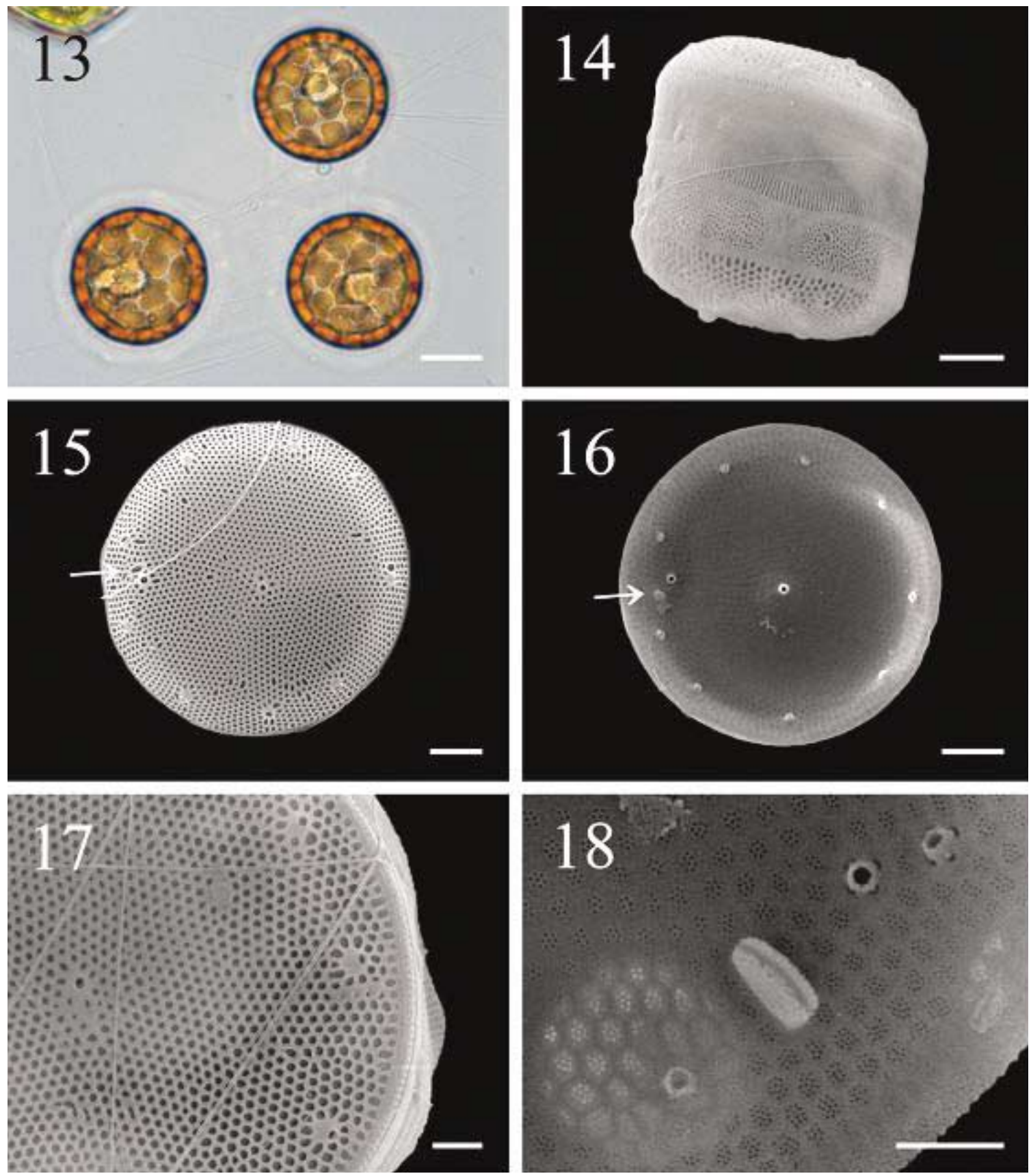

Plate III. Thalassiosira minuscula, LM and SEM. Fig. 13. LM. Fig. 14. External girdle view. Fig. 15. External valve view showing the labiate process (arrow). Fig. 16. Internal valve view showing the labiate process (arrow) and a marginal strutted processes. Fig. 17. Central and marginal strutted processes and areolation. Fig. 18. Focusing on the labiate process and one sub-marginal strutted process with four satellite pores. Scale bar: $10 \mu \mathrm{m}$ (Fig. 13), $2 \mu \mathrm{m}$ (Figs 14-16), $1 \mu \mathrm{m}$ (Figs 17-18).

Basionym: Ethmodiscus punctiger Castracane

Synonym: Ethmodiscus punctiger Castracane; Coscinodiscus punctiger (Castracane) Peragallo; Coscinodiscus verecundus Mann; Coscinodiscus angstii Gran; Thalassiosira japonica Kiselev; Thalassiosira angstii (Gran) Makarova.

Cells slightly convex in the girdle view. Cells $62-74 \mu \mathrm{m}$ in diameter. Valve with fine fasciculated areolation and ribbed margin. Areolae 20 to 23 in $10 \mu \mathrm{m}$. One central strutted process in the valve center. One marginal ring of strutted processes showing an external tulip-shaped. One ring of occuluded processes located ring of marginal strutted processes inside in the external view. In the internal view, one ring of widely spaced, variable in number of large occluded marginal processes could be present. One external tube of labiate process just positioned inside the marginal ring. In internal view, margin- 

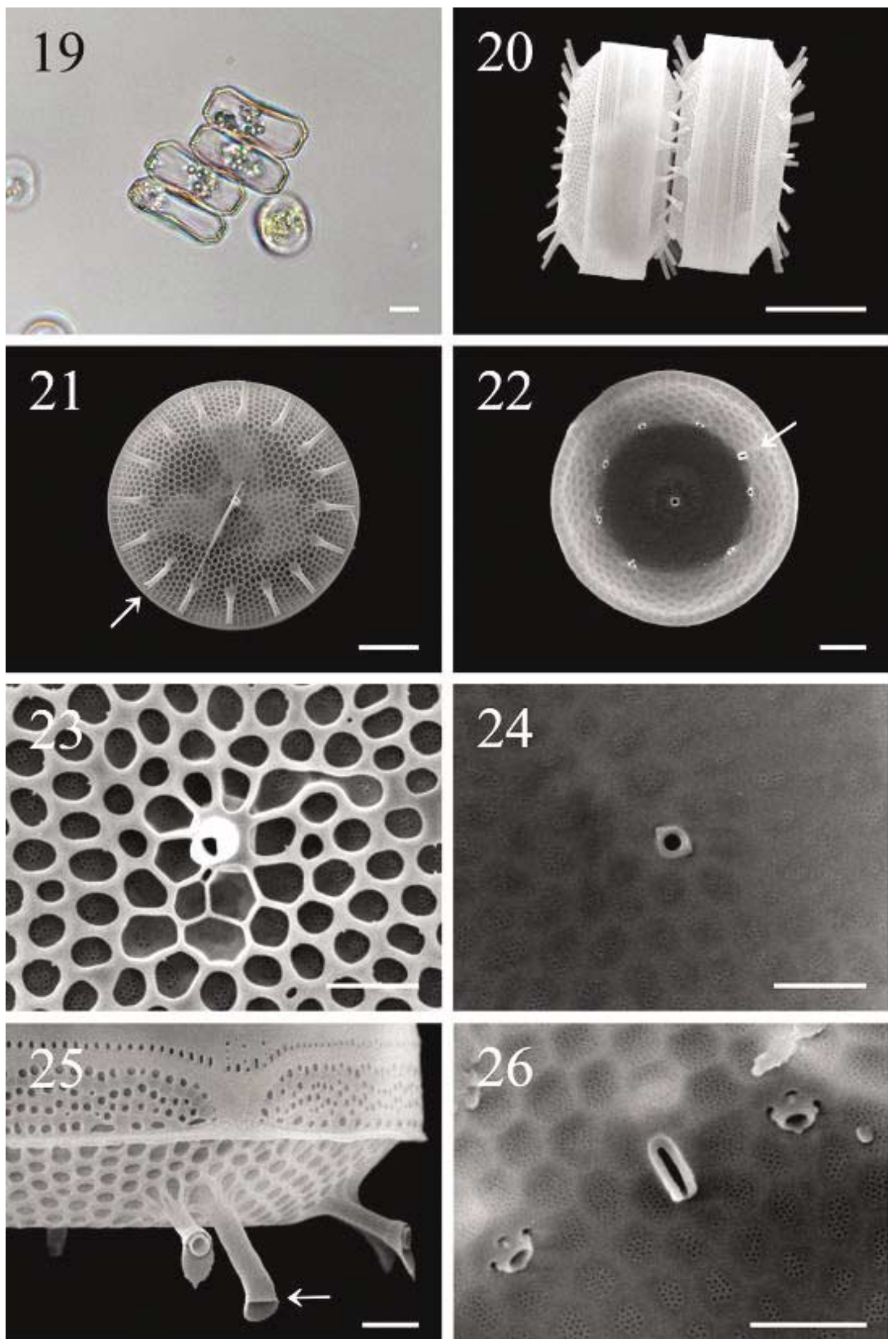

Plate IV. Thalassiosira nordenskioeldii, LM and SEM. Fig. 19. Cell colony formation in LM. Fig. 20. Two cells in the external girdle view.

Fig. 21. External valve view showing the external tube of labiate process (arrow). Fig. 22. Internal valve view showing the labiate process (arrow) and marginal strutted processes. Fig. 23. Central strutted process and areolation. Fig. 24. Central strutted process with two satellite pores. Fig. 25. External tube of labiate process (arrow) and long marginal strutted process. Fig. 26. Focusing on labiate process and marginal strutted processes. Scale bar: $10 \mu \mathrm{m}$ (Figs 19-21), $2 \mu \mathrm{m}$ (Fig. 22), $1 \mu \mathrm{m}$ (Figs 23-26). 

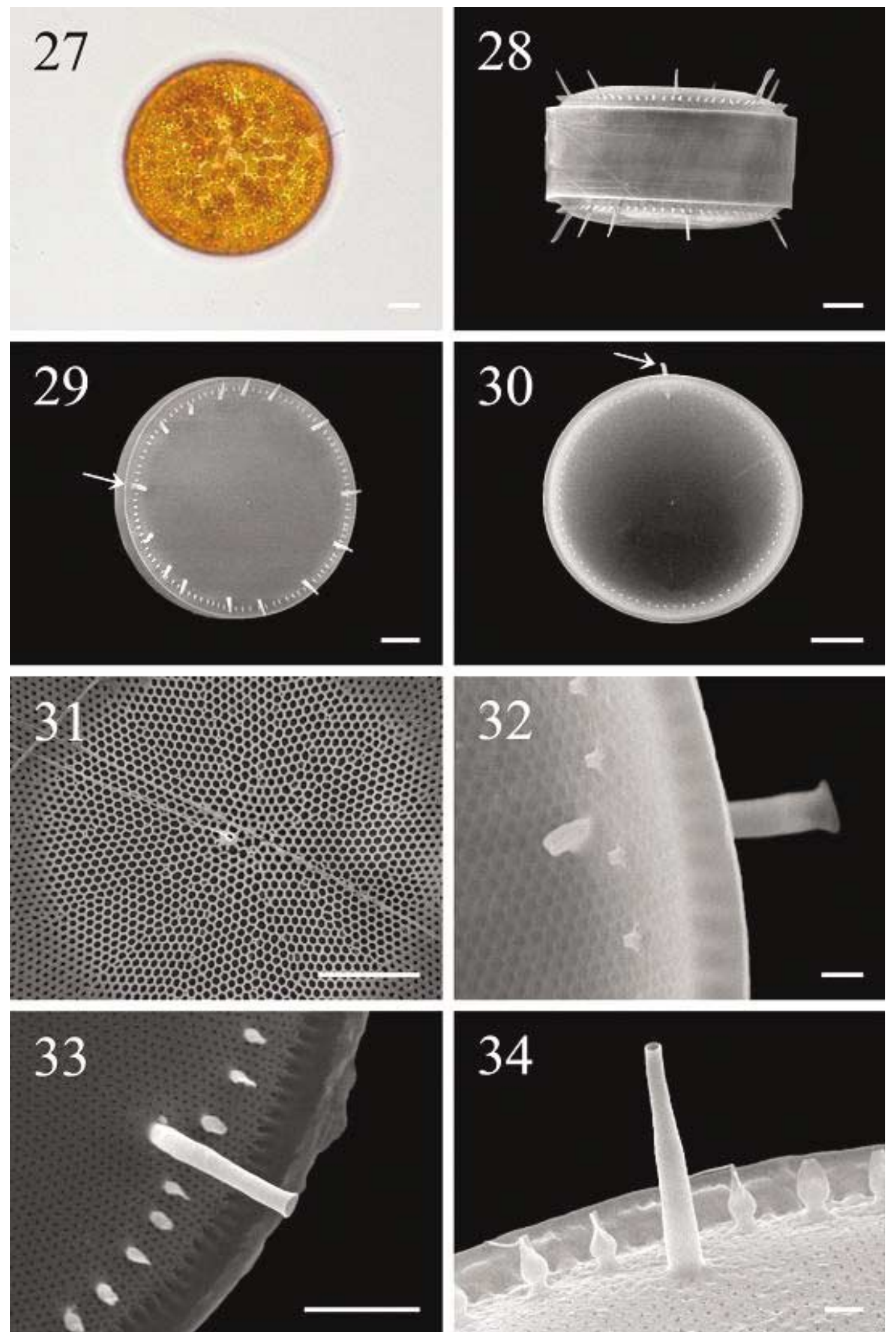

Plate V. Thalassiosira punctigera, LM and SEM. Fig. 27. LM. Fig. 28. External girdle view showing the external tube of labiate process (arrow) and occluded processes. Fig. 29. External valve view showing the external tube of labiate process (arrow), occluded processes and marginal strutted processes. Fig. 30. Internal valve view showing the labiate process and marginal strutted processes. Fig. 31. Central strutted process and radial areolation of valve face. Fig. 32. Focusing on labiate process. Fig. 33. External tube of the labiate process and a marginal strutted processes. Fig. 34. Occluded process and jar-shaped marginal strutted processes. Scale bar: $10 \mu \mathrm{m}$ (Figs 27-30), $5 \mu \mathrm{m}$ (Figs 31, 33), $1 \mu \mathrm{m}$ (Figs 32, 34). 

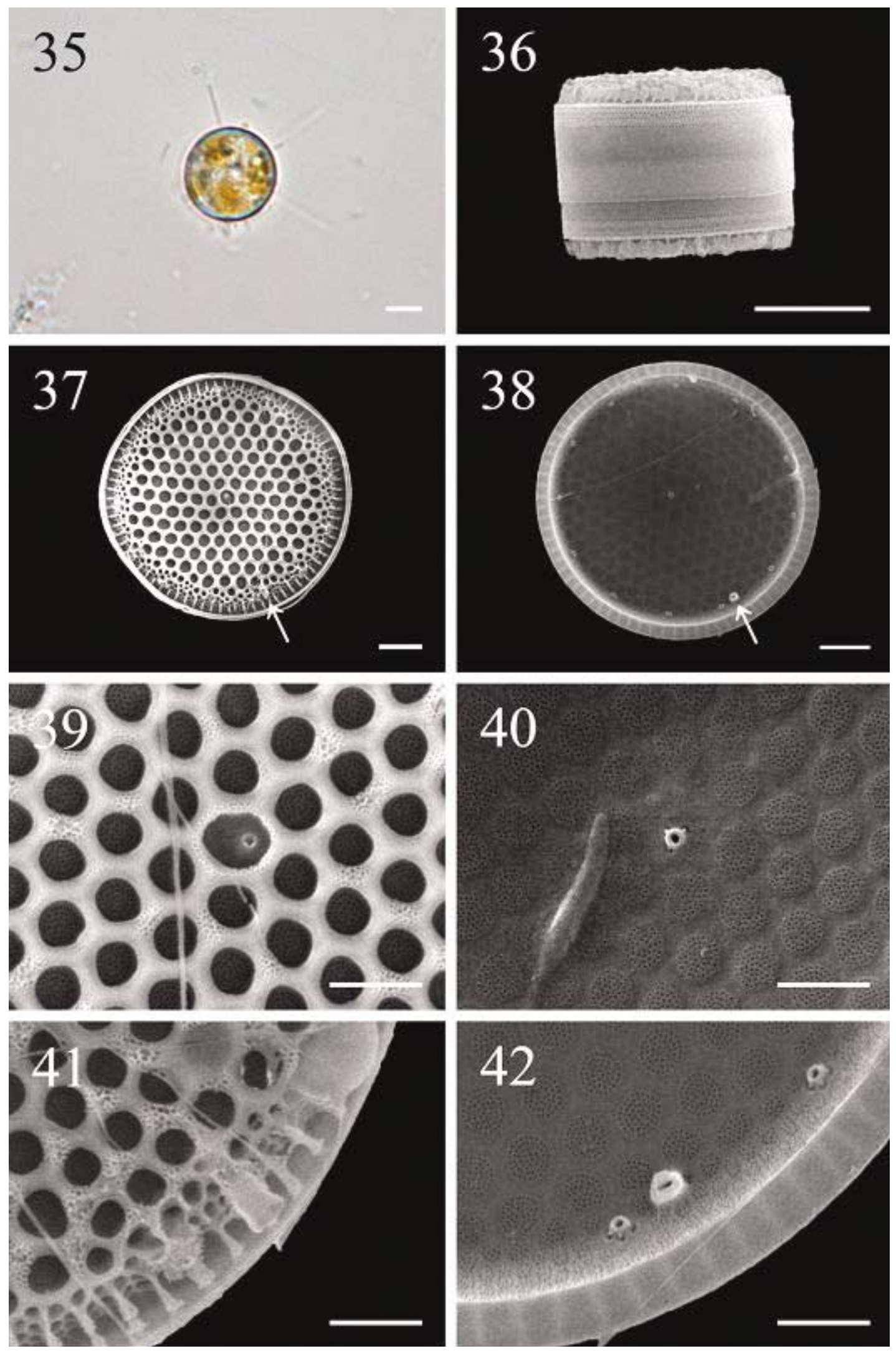

Plate VI. Thalassiosira tenera, LM and SEM. Fig. 35. Small living cell in LM. Fig. 36. External girdle view. Fig. 37. External valve view showing areolation and the external tube of labiate process (arrow). Fig. 38. Internal valve view showing the labiate process (arrow) and marginal strutted processes. Fig. 39. Central strutted process and areola situation. Fig. 40. Central strutted process with three satellite pores. Fig. 41. External tube of labiate process and marginal strutted process. Fig. 42. Focusing on labiates process and marginal strutted processes. Scale bar: $5 \mu \mathrm{m}$ (Fig. 35), $2 \mu \mathrm{m}$ (Figs 36, 38), $1 \mu \mathrm{m}$ (Figs 37, 39-42). 
Table 2. Morphological character of Thalassiosira species from Aug. 2006 to Mar. 2008 in Korean costal waters

\begin{tabular}{|c|c|c|c|c|c|c|c|c|}
\hline \multirow[t]{2}{*}{ species } & \multirow{2}{*}{$\begin{array}{l}\text { Diameter } \\
(\mu \mathrm{m})\end{array}$} & \multicolumn{2}{|c|}{ Areolae in $10 \mu \mathrm{m}$} & \multicolumn{2}{|c|}{ Number \& features of strutted process } & \multicolumn{2}{|c|}{ Labiate process feature } & \multirow{2}{*}{$\begin{array}{c}\text { Occluded } \\
\text { process }\end{array}$} \\
\hline & & $\begin{array}{l}\text { Valve } \\
\text { face }\end{array}$ & $\begin{array}{c}\text { Valve } \\
\text { margina }\end{array}$ & valve face & Marginal ring & $\begin{array}{l}\text { External } \\
\text { tube }\end{array}$ & Internal form & \\
\hline $\begin{array}{l}\text { Thalassiosira curviseriata } \\
\text { Takano }\end{array}$ & $\begin{array}{l}8-10 \\
(n=5)\end{array}$ & $20-25$ & $35-40$ & $\begin{array}{l}\text { One or two } \\
\text { central }\end{array}$ & & Present & & None \\
\hline T. lundiana Fryxell & $\begin{array}{l}10-36 \\
(n=49)\end{array}$ & $17-36$ & $17-36$ & $\begin{array}{c}\text { One central, } \\
\text { Many sub-central } \\
\text { scattered }\end{array}$ & & Present & & $\begin{array}{l}\text { Many in } \\
\text { the margin }\end{array}$ \\
\hline T. minuscula Krasske & $\begin{array}{l}11-14 \\
(\mathrm{n}=13)\end{array}$ & $40-50$ & $40-50$ & One central & 8 & $\begin{array}{l}\text { None }^{1} \text { or } \\
\text { Present }^{2}\end{array}$ & & None \\
\hline T. nordenskioeldii Cleve & $\begin{array}{l}11-41 \\
(n=12)\end{array}$ & $11-22$ & $14-18$ & One central & & Present & & None \\
\hline $\begin{array}{l}\text { T. punctigera } \\
\text { (Castracane) Hasle }\end{array}$ & $\begin{array}{l}62-74 \\
(\mathrm{n}=33)\end{array}$ & $20-23$ & $20-23$ & One central & & Present & & $\begin{array}{l}\text { Many in } \\
\text { the margin }\end{array}$ \\
\hline $\begin{array}{l}\text { T. tenera } \\
\text { Proshkina-Lavrenko }\end{array}$ & $\begin{array}{l}9-12 \\
(n=9)\end{array}$ & $15-20$ & $40-45$ & One central & & Present & & None \\
\hline
\end{tabular}

${ }^{1}$ Present study, ${ }^{2}$ Hoppenrath et al. 2007

al strutted processes composed with 4 satellite pores and little extension.

Distribution: Thalassiosira punctigera was known to wide distribution; warm to temperate waters (Hasle 1983). In Korean coatal waters, T. punctigera was recorded 11 times till the year of 1990's (Lee 1995), and the present study was collected in January 13, 2007 in Tongyeong coastal waters.

\section{Taxonomic remarks}

Hasle (1983) suggested that 8 taxa reduced to synonym with Thalassiosira punctigera (Castracane) comb. nov., an extremely variable species as to size and valve structure. Occluded process may be also able to striking feature of Thalassiosira punctigera, however occluded processes may or may not be present in this species. T. punctigera have specific shape of external long tube. Marginal strutted processes was tulip-shaped and this character is striking feature of T. punctigera.

\section{Thalassiosira tenera Proschkina-Lavrenko (P1. VI, Figs 35-42)}

Proschkina-Lavrenko 1961, p. 33, Pl. 1, Figs 1-4, Pl. 2, Figs 5-7; Hasle and Fryxell 1977, p. 28, Pl. 12 and 13, Figs 54-65; Takano 1980c, sheet 33, Figs A-F; Harris et al. 1995, p. 121, Figs 6 and 24.

Cells rectangular in the girdle view. Cells 9-12 $\mu \mathrm{m}$ in diameter. Valve with straight and/or linear areolation with relatively coarse hexagonal areolae. Number of areolae $15-20$ in $10 \mu \mathrm{m}$. One central strutted process positioned in one central areolae and surrounded by a central areola slightly larger than the other areolae. One marginal ring of closely standing tooth-shaped strutted processes. One labiate processes in the marginal ring directly next to a strutted one. In the internal view, central strutted process composed with 3 satellite pores, whereas marginal strutted processes with 4 satellite pores. Labiate process size smaller than other Thalassiosira species in the present study.

Distribution: Thalassiosira tenera was known to cosmopolitan species by Hasle and Fryxell (1977). Takano (1980b) reported the distribution from Yokohama coastal 
waters to several estuarine of Japan. Our specimens were found in December 20, 1998 in Jinding Bay and March 23, 2008 in Seocheon coastal water and new to Korea.

\section{Taxonomic remarks}

Thalassiosira tenera and T. exigua are very similar species. Hasle and Fryxell (1977) have pointed out that the differences between these species are the smaller diameter of the former as well as the structure of the valvocopula. Aké-Castillo et al. (1999) have pointed out that the differences are the marginal costae, cribra structure, satellite pores. However, Hasle and Fryxell (1977) have mentioned that the satellite pores are variable. The present study showed that the shape of external tube of marginal strutted process was enclosed with siliceous. Marginal strutted process was tooth-shaped in the external view.

Since phytoplankton studies in the coastal waters of the Korean Peninsula were begun in the early of 1930's, most papers published on the phytoplankton diatoms ecology to be focused on the spatial and temporal distribution. The systematics and taxonomy of the marine phytoplankton diatoms were not many papers. Lee and Yoo $(1986,1987)$ have studied for the first time the fine structure, description, ecology and taxonomic remarks of the genus Thalassiosira 10 species by means of light microscope and scanning electron microscope in the Korean coastal waters. Although thereafter many papers on the taxonomy were published in earnest; pennate diatoms (Choi and Noh 1987), six Cyclotella species (Lee and Lee 1988), 2 Coscinodiscus species (Lee 1989; Lee et al. 1992), Roperia tesselata (Lee and Lee 1990), the family Hemicadiscaceae (Lee et al. 1992), Pseudohimantidium pacificum (Lee et al. 1993), there were not rich papers in Korea.

Thalassiosira, with its more than 100 species, is one of the most biggest planktonic genus in marine environment (Round et al. 1990; Hasle and Syversten 1996). Also, the genus is most throughly examined in the world. By reason of a small-sized cells of Thalassiosira, there were no active works except Lee and Yoo $(1986,1987)$ in Korea. It is absolutely necessary for excellent studies of the Thalassiosira species to need scanning electron microscope.

\section{ACKNOWLEDGEMENTS}

The investigation was supported by grants from Sangmyung University in the year of 2008 and No. 2007-
491-1 “The Survey of Indigenous Biological Resources of Korea" from National Institute of Biological Resources (NIBR). Thanks are due to all who in various ways helped with sampling materials and technical assistance for this investigation, S.W. Jung, S.J. Yoon, S.W. Shin and S.M. Yoon in Department of Life Science, Sangmyung University of Korea.

\section{REFERENCES}

Anonymous 1975. Proposals for a standardization of diatom terminology and diagnoses. Nova Hedwigia, Beih. 53: 323354.

Aké-Castillo J.A., Hernández-Becerril D.U. and Meave del Castillo M.E. 1999. Species of the Genus Thalassiosira (Bacillariophyceae) from the Gulf of Tehuantepec, Mexico. Bot. Mar. 42: 487-503.

Castracane A.F. 1886. Report on the Diatomaceae. Report of the scientific results of the voyage of the H.M.S. Challenger during the years 1873-6. Challenger Reports, Bot. 2: 1-178.

Choi J.K. and Noh J.H. 1987. The fine structure of new recorded pennate diatoms in Korea. Korean J. Phycol. 2: 97-117.

Cleve P.T. 1873. On diatoms from the Arctic Sea. Bihang till Kongliga Svenska Vetenskaps-Akademiens Handlingar 1: 1-28.

Cupp E.E. 1943. Marine plankton diatoms of west coast of North America. Bull. Scripps Inst. Oceanogr., Univ. California. 5: 1-238.

Fryxell G.A. 1975. Three new species of Thalassiosira, with observations on the occluded process, a newly observed structure of diatom valves. Nova Hedwigia, Beih. 53: 57-82.

Fryxell G.A. 1978. The diatom genus Thalassiosira: T. licea sp. nov. and T. angstii (Gran) Makarova, species with occluded processes. Bot. Mar. 21: 131-141.

Hallegraeff G.M. 1984. Species of the diatom genus Thalassiosira in Australian waters. Bot. Mar. 27: 495-513.

Han M.S., Kim Y.O. and Jeon J.K. 1994. Changes in phytoplankton community in structure in the two different hydrological conditions of semi-enclosed Chinhae Bay, Korea. Bull. Plankton Soc. Japan 41: 43-55.

Harris A.S.D., Medlin L.K., Lewis J. and Jones J. 1995. Thalassiosira species (Bacillariophyceae) from a Scottish sealoch. Eur. J. Phycol. 30: 117-131.

Hasle G.R. 1968. The valve processes of the centric diatom genus Thalassiosira. Nytt Mag. Bot. 15: 193-201.

Hasle G.R. 1972. Thalassiosira subtilis (Bacillariophyceae) and two allied species. Norw. J. Bot. 19: 111-137.

Hasle G.R. 1973. Thalassiosiraceae, a new diatom family. Norw. J. Bot. 20: 67-69.

Hasle G.R. 1976a. Examination of diatom type material: Nitzschia delicatissima Cleve, Thalassiosira minuscula Krasske, and Cyclotella nana Hustedt. Br. J. Phycol. 11: 101-110.

Hasle G.R. 1976b. The biography of some marine planktonic diatoms. Deep Sea Res. 23: 319-338.

Hasle G.R. 1978. Some Thalassiosira species with one central process (Bacillariophyceae). Norw. J. Bot. 25: 77-110. 
Hasle G.R. 1983. Thalassiosira punctigera (Castr.) comb. nov., a widely distributed marine planktonic diatom. Nord. J. Bot. 3: 593-608.

Hasle G.R. and Fryxell G.A. 1970. Diatoms: Cleaning and mounting for light and electron microscopy. Tans. Am. Microsc. Soc. 89: 469-474.

Hasle G.R. and Fryxell G.A. 1977. The genus Thalassiosira: some species with a linear areola array. Nova Hedwigia, Beih. 54: $15-66$.

Hasle G.R. and Syversten E.E. 1996. Marine diatoms. In: Tomas C.R. (ed.), Identifying marine diatoms and dinoflagellates. Academic Press, Inc. pp. 5-386.

Helmcke J.-G. and Krieger W. 1953. Diatomeenschalen im elektronenmikroskopischen Bild 1. Cramer, Weinheim, 19 pp. plates 1-102.

Helmcke J.-G. and Krieger W. 1954. Diatomeenschalen im elektronenmikroskopischen Bild 2. Cramer, Weinheim, 24 pp. plates 103-200.

Hendey N.I. 1964. An introductory account of the smaller algae of British coastal waters. Part V. Bacillariophyceae (Diatoms). Minstry of Agriculture, Fisheries and Food Fishery Investigations Ser. IV., H.M.S.O. London, 317 pp.

Hernández-Becerril D.U. and Tapis-Peña M.I. 1995. Planktonic diatoms from the Gulf of California and coasts off Baja California: species of the genus Thalassiosira. Bot. Mar. 38: 543-555.

Hoppenrath M., Beszteri B., Drebes G., Halliger H., Beusekom J.E.E.V., Janisch S. and Wiltshire K.H. 2007. Thalassiosira species (Bacillariophyceae, Thalassiosirales) in the North Sea at Helgoland (German Bight) and Sylt (North Frisian Wadden Sea) - a first approach to assessing diversity. Eur. J. Phycol. 42: 271-288.

Hustedt F. 1930. Die Kieselalgen Deutschlands, Osterreichs und der Schweiz. In: Rabenhorst (ed.), Kryptogamen-Flora von Deutschlands, Osterreichs und der Schweiz. Akademische Verlagsgesellschaft mbH, Leipzig. pp. 1-920.

Krasske G. 1941. Die kieselalgen des chilenischen Küstenplanktons. Archiv für Hydrobiologie 38: 260-287.

Lebour M.V. 1930. The planktonic diatoms of Northern seas. Ray Society, London, $244 \mathrm{pp}$.

Lee J.H. 1989. Special issue for Korea-Japan symposium on phycology/morphology, taxonomy and life histories: The diatom genus Coscinodiscus Ehrenberg: C. jonesianus (Ehrenb.) Ostenfeld. Korean J. Phycol. 3: 133-145.

Lee J.H. 1995. Additional check-list of marine planktonic algae in the coastal waters of Korea. I. Bacillariophyceae. J. Natural Sci., Sangmyung Women's Univ. 2: 71-198.

Lee J.H., Byun J.S. and Lee E.H. 1992. Taxonomy and phylogeny of the marine diatom family Hemidiscaceae in the Korean coastal waters. Korean J. Phycol. 7: 185-205.

Lee J.H. and Cho C.H. 1985. Check-list of marine planktonic algae in the coastal waters of Korea. I. Bacillariophyceae. Ocean Research 7: 19-47.

Lee J.H., Jung Y.H. and Choi C.I. 1992. Special issue for 2nd Japan-Korea symposium on phycology/taxonomy and morphology: The diaom genus Coscinodiscus Ehrenberg: $C$. wailesii Gran \& Angst. Korean J. Phycol. 7: 55-62.

Lee J.H. and Lee E.H. 1988. A taxonomic study on the genus Cyclotella, Bacillariophyceae, in Korean waters. Korean J. Phycol. 3: 133-145.

Lee J.H. and Lee J.Y. 1990. A light and scanning electron microscopic study on the marine diatom Roperia tesselata (roper) grunow. Diatom Res. 5: 325-335.

Lee J.H., Lee. J.Y. and Kim M.O. 1993. The fine structure of the marine epizoic pennate diatom Pseudohimantidium pacificum in Korean coastal waters. J. Oceanol. Soc. Korea 28: 202-211.

Lee J.H. and Yoo K.I. 1986. A study on the fine structure of the marine diatoms of Korean coastal waters-Genus Thalassiosra 1. J. Oceanol. Soc. Korea 21: 184-192.

Lee J.H. and Yoo K.I. 1987. A study on the fine structure of the marine diatoms of Korean coastal waters-Genus Thalassiosra 2. J. Oceanol. Soc. Korea 22: 179-190.

Mahood A.D., Fryxell G.A. and McMillan M. 1986. The diatom genus Thalassiosira: species from the San Francisco Bay system. Pro. Calif. Acad. Sci. 44: 127-156.

Makarova I.V. 1970. Ad taxonomiam specierum nonnullarum generis Thalassiosira Cl. Novitates Systematicae Plantarum non Vascularium 7: 13-20.

Makarova I.V. 1988. Diatomovie vodorosli morei SSSR: rod Thalassiosira Cl. USSR Acad. Sci. Nauka, Leningrad, 116. pp. (In Russian).

Proshkina-Lavrenko A.I. 1961. Diatomeae novae e Mari Nigro (Ponyo Euxino) et Azoviano (Maeotico). Notul. syst. Inst. cryptog. URSS 14: 33-39.

Rivera P. 1981. Beiträge zur Taxonomie und Verbreitung der Gattung Thalassiosira Cleve (Bacillariophyceae) in den Küstengewässern Chiles. Bibl. Phycol. 56: 1-220.

Round F.E., Crawford R.M. and Mann D.G. 1990. The diatoms: biology and morphology of the genera. Cambridge, $747 \mathrm{pp}$.

Simonsen R. 1974. The diaom plankton of the Indian Ocean Expedition of RV "Meteor" 1964-1965. "Meteor" Forsch. Ergebn., Reihe D. 19: 1-107.

Simonsen R. 1979. The diatom system: ideas on phylogeny. Bacillaria 2: 9-71.

Syvertsen E.E. and Hasle G.R. 1984. Thalassiosira bulbosa Syversten, sp. nov., an Arctic marine diatom. Polar Biol. 3: $167-172$

Takano H. 1979a. Thalassiosira lundiana Fryxell. In: The working party on taxonomy in the Akashiwo Kenkyukai (ed.), Synopsis of red-tide organisms. sheet no. 14. c/o Fishery Agency, Japan. sheet. pp. 1-30. rewrite!!

Takano H. 1979b. Thalassiosira nordenskioeldii Cleve. In: The working party on taxonomy in the Akashiwo Kenkyukai (ed.), Synopsis of red-tide organisms. sheet no. 9. c/o Fishery Agency, Japan. sheet. pp. 1-30 rewrite!!

Takano H. 1980a. New and rare diatoms from Japanese marine waters-V. Thalassiosira tealata sp. nov. Bull. Tokai Reg. Fish. Res. Lab. 103: 55-63.

Takano H. 1980b. Thalassiosira punctigera (Castracaene) Hasle. In: The working party on taxonomy in the Akashiwo Kenkyukai (ed.), Synopsis of red-tide organisms. sheet no. 32. c/o Fishery Agency, Japan. sheet. pp. 31-60. 
Takano H. 1980c. Thalassiosira tenera Proschkina-Lavrenko. In: The working party on taxonomy in the Akashiwo Kenkyukai (ed.), Synopsis of red-tide organisms. sheet no. 33. c/o Fishery Agency, Japan. sheet. 31-60.

Takano H. 1981. New and rare diatoms from Japanese marine waters. VI. Three new species in Thalassiosiraceae. Bull. Tokai Reg. Fish. Res. Lab. 105: 31-43.
Takano H. 1983. Thalassiosira curviseriata Fryxell. In: The working party on taxonomy in the Akashiwo Kenkyukai (ed.), Synopsis of red-tide organisms. sheet no. 123. c/o Fishery Agency, Japan. sheet. 121-150.

Received 4 August 2008

Accepted 28 August 2008 
